\title{
Relationship Between Mast Cell Subtypes and Cyclooxygenase-2 Expression in Uterine Leiomyomas
}

\author{
Uterin Leiomyomalarda Mast Hücre Subtipleri ve Siklooksijenaz-2 Ekspresyonu Arasındaki iliş̧ki
}

Azize Yasemin Göksu Erol'1, Fatma Aktepe², Çiğdem Tokyol², Mehmet Yılmazer³, Tolga Dağıstan Arıöz³, Öner Özdemir

1'Department of Medical Genetics, Faculty of Medicine, Süleyman Demirel University, Isparta, Turkey

2Department of Pathology, Faculty of Medicine, Afyonkocatepe University, Afyon, Turkey

${ }^{3}$ Department of Obstetrics and Gynecology, Faculty of Medicine, Afyonkocatepe University, Afyon, Turkey

${ }^{4}$ Department of Pediatrics, İstanbul Civilization University, İstanbul, Turkey

\begin{abstract}
Objective: Mast cells (MCs) have been proved to be multifunctional cells which are known to be located at peri-and intra-tumoral sites, playing an active role physiologically or pathologically. In humans, MCs are subtyped by the difference in their neutral protease content. MCs that have granules containing tryptase alone (MCT) are predominantly found at mucosal sites. MCs whose granules possess tryptase along with chymase (MCTC) are found especially within connective tissue. MC mediators have different functions and the coexistence of both MC subtypes contributes to tissue homeostasis. Furthermore, cyclooxygenase-2 (COX-2) is an enzyme associated with inflammation, cell growth and differentiation, prevention of apoptosis and tumorigenesis. Recent studies show the clinical significance of COX-2 expression in different tumor types. However, to our knowledge, there is no data assessing the relationship between COX-2 and MC density in uterine leiomyomas. We aimed to investigate the relation between the expression of COX-2, MC density, and proportional changes of MC phenotypes in human leiomyoma uteri and control cases, and also their possible correlations between each other.
\end{abstract}

Methods: We performed a retrospective study of 34 cases carried out on parafin-embedded samples obtained from 14 control (group 1 ) and 20 leiomyoma uteri (group 2) patients who had undergone curative hysterectomy. These specimens were investigated immunohistochemically by using anti-cyclooxygenase-2 (COX-2) antibodies to stain COX-2; anti-tryptase antibodies to stain MCT and anti-chymase antibodies to stain MCTC.

Results: In leiomyoma, the median value of COX-2 staining grade was 2 (min:1-max:3) which was statistically lower than that of controls with a median value of 3 (min:2-max:4) ( $p=0.001)$. The median value of tryptase expression was 12 (min:10-max:16) in the control myometrium, slightly higher than that of the leiomyoma group which had a median value of 10.5 (min:6-max:15). On the other hand, the median value of chymase expression was 7 (min:4-max:13) in the control myometrium, which was significantly higher $(p=0.001)$ than that of the leiomyoma group with a median value of 5 (min:2max:8). Thus, in the leiomyoma group, the mast cell subtypes, including tryptase - chymase proportion, was found to be significantly higher than the controls ( $p=0.032$ ). Moreover, COX-2, tryptase and chymase expressions showed no correlation in both groups.

Conclusion: This study has demonstrated that expressions of COX-2 and mast cell subtypes are reduced in leiomyoma, and the proportion of mast cell subtypes of $\mathrm{MCT} \div \mathrm{MCTC}$ increases in leiomyoma compared to the control group. However, $\mathrm{MC}$ subtypes neither correlated with each other nor with COX-2 expression in the leiomyoma and control series. Understanding the mechanisms for MC functions and the secretory molecules will provide a basis for a rational approach to the development of antitumoral therapy in patients with leiomyoma and other tumors. (JAREM 2011; 1: 44-8)

Key Words: Mast cells, tryptase, chymase, cyclooxygenase-2, uterine leiomyomas

\section{ÖZET}

Amaç: Mast hücreleri (MH'ler)'nin çok fonksiyonlu hücreler olduğu ispatlanmış olup, peri- ve intra-tümöral bölgelerde yerleşim göstererek fizyolojik yada patolojik olarak aktif bir rol oynadıkları bilinmektedir. Insanlarda MH'ler, içerdikleri nötral proteaz farklılığına göre subtiplere ayrılırlar. Sadace triptazı içeren granüllere sahip olan $\mathrm{MH}^{\prime}$ ler (MCT), ağırlıklı olarak mukozal bölgelerde bulunurlar. Granülleri triptaza ek olarak kimaz içeren $\mathrm{MH}$ 'ler ise, özellikle bağ dokusunda yer alırlar. MH mediyatörleri farklı fonksiyonlara sahiptirler ve her iki MH subtipi, doku hemostazına katılım gösterirler. Ayrıca, siklooksijenaz-2 (COX-2), inflamasyon, hücre büyümesi ve farklılaşması, apoptozun önlenmesi ve tumorigenez ile ilişkili bir enzimdir. Yakın zamandaki çalışmalar, farklı tümör tiplerinde COX-2 ekspresyonunun klinik önemini göstermektedir. Ancak, bildiğimiz kadarıyla, uterin leiomyomalarında, COX-2 ve $\mathrm{MH}$ dansitesinin arasındaki ilişkiyi değerlendiren herhangi bir veri bulunmamaktadır. Biz de, insan leiomyoma ve kontrol vakalarında COX-2 ekspresyonu ve $\mathrm{MH}$ dansitesi arasındaki ilişkiyi ve $\mathrm{MH}$ fenotiplerinin oransal farklılıklarını ve birbirleriyle olan korelasyonlarını araştırmayı amaçladık.

Yöntemler: Otuz dört vakadan oluşan retrospektif olarak yürüttüğümüz çalışmada kuratif histerektomi yapılmış 14 kontrol (grup 1) ve 20 uterin leiomyoma (grup 2) hastasının parafine gömülü örnekleri elde edildi. Bu örnekler, COX-2'yi boyamak için anti-COX-2 antikorları, MCT'yi boyamak için anti-triptaz antikorları ve MCTC'yi boyamak için anti-kimaz antikorları kullanılarak immünohistokimyasal olarak incelendi.

Bulgular: Leiomyomada COX-2 boyanma derecesinin median değeri 2 (min:1-maks:3) olarak, kontrolün median değeri olan 3 (min:2-maks:4)'e oranla istatistiksel olarak anlamlı derecede daha düşüktü ( $p=0.001$ ). Triptaz ekspresyonunun median değeri kontrol myometriumunda 12 (min:10-maks:16) olarak, leiomyoma grubunun 10.5 (min:6-maks:15) olan median değerinden hafif derecede yüksekti. Diğer taraftan, kimaz ekspresyonunun median değeri kontrol myometriumunda 7 (min:4-maks:13) olarak, leiomyoma grubunun 5 (min:2-maks:8) olan median değerine göre belirgin derecede yüksekti ( $p=0.001$ ). Böylece, leiomyoma grubunda triptaz içeren $\mathrm{MH} \div$ kimaz içeren $\mathrm{MH}$ oranı kontrole kıyasla belirgin derecede yüksek olarak bulundu $(p=0.032)$. Dahası, COX-2, triptaz ve kimaz ekspresyonları her 2 grupta da korelasyon göstermedi.

Address for Correspondence / Yazışma Adresi: Dr. Azize Yasemin Göksu Erol, Department of Medical Genetics, Faculty of Medicine, Süleyman Demirel University, Isparta, Turkey Phone: +90246 2371727 E-mail: yasemin.goksu@gmail.com
Received Date / Geliş Tarihi: 15.09.2011 Accepted Date / Kabul Tarihi: 18.10.2011 (c) Telif Hakkı 2011 AVES Yayınclık Ltd. Şti. Makale metnine www.jarem.org web sayfasından ulaşlabilir. (C) Copyright 2011 by AVES Yayınclik Ltd. Available on-line at www.jarem.org doi: 10.5152/jarem 2011.13 
Sonuç: Bu çalışma, leiomyomada COX-2 ve MH subtiplerinin ekspresyonlarının azaldığını ve $\mathrm{MH}$ subtipleri olan $\mathrm{MCT} \div \mathrm{MCTC}$ oranının kontrole göre arttığını gösterdi. Ancak, MH subtipleri kendi aralarında yada COX-2 ekspresyonu ile arasında herhangi bir korelasyon göstermedi. Bu bağlamda, MH fonksiyonlarının ve sekretuar moleküllerinin işleyiş mekanizmalarını anlamak, leiomyoma ve diğer tümörlere sahip hastalarda anti-tümöral tedavi geliştirmede mantıklı bir yaklaşım için bir taban oluşturacaktır. (JAREM 2011; 1: 44-8)

Anahtar Sözcükler: Mast hücreleri, triptaz, kimaz, siklooksijenaz-2, uterin leiomyomalar

\section{INTRODUCTION}

Uterine leiomyomas are generally considered as benign neoplasms. Nevertheless, they are the most common indication for gynecological surgery. They occur in about $20-40 \%$ of women during the reproductive years (1). Limited knowledge about their biology makes it difficult to develop satisfactory non-surgical treatments. However, the pathogenesis of leiomyomas has been widely studied and many growth factors have been implicated in their pathogenesis $(2,3)$.

Mast cells (MCs) have been proved to be multifunctional cells which are known to be located at peri- and intra-tumoral sites, playing an active role physiologically or pathologically. In the second half of the 1990s, a close correlation between MCs and angiogenesis was noted in cancers, angiomas, lymphomas, and multiple myeloma $(4,5)$. In these neoplasms, MCs were detected on the tumor periphery, in the surrounding connective tissue, and in the vicinity of lymphatic and blood vessels.

In humans, MCs are subtyped by the difference in neutral protease (6). MCs with granules containing the protease tryptase alone (MCT) are predominantly found at mucosal sites, and MCs whose granules possess tryptase along with chymase (MCTC) are found especially within connective tissue. T cell-derived growth factors play an important role in the development and maintenance of MCT at mucosal sites (7). MCT and MCTC also display functional heterogeneity, with the former producing both IL-5 and IL-6, and the latter producing only IL-4 (8). Despite these differences, it is thought that the above phenotypes are plastic and interchangeable. MC mediators cause different functions and the coexistence of both MC subtypes contributes to tissue homeostasis. Furthermore, increased/decreased MCD may or may not be associated with proportional changes of MC subtypes. This phenotypic change could be basically modified by the environment (9).

Furthermore, cyclooxygenase-2 (COX-2) is an inducible immediate early gene associated with inflammation, cell growth and differentiation, prevention of apoptosis and tumorigenesis (10). Current studies suggest a clinical significance of COX-2 expression in different tumor types. Recently, it has been reported that COX-2 contributes to angiogenesis involved in tumor growth and advancement of various tumors $(11,12)$. Nevertheless, a close association of COX-2 expression and MCs in colon cancer has also been reported and an anti-tumoral effect of MCs was proposed (13). In addition, COX-2 expression is reported to correlate with tumor angiogenesis in patients with hepatitis $(14,15)$.

However, to our knowledge, there is no data assessing the relationship between COX-2 and MCD in uterine leiomyomas. We aimed to determine the relation between COX-2 expression, MCD and proportional changes of MC phenotypes in leiomyoma uteri and control cases.

\section{MATERIAL AND METHODS}

\section{Tissue samples and Patient characteristics}

We performed a retrospective study of 34 cases, carried out on parafin-embedded samples obtained from 14 control (Group 1),
20 leiomyoma uteri (Group 2) patients who had undergone curative hysterectomy at the Department of Obstetrics and Gynecology in Afyon Kocatepe University. Diagnosis was made according to the pathologic findings in all cases.

The ages of 14 control cases were between 37 and 53 years of age, with a mean value of 45.7. The ages of 20 patients of leiomyoma cases were between 42 and 55 years of age, with a mean value of 47.4, which shows a statistically nonsignificant difference compared to the control value. Each case was immunohistochemically analysed by using anti-tryptase antibody to stain MCT and anti-chymase antibody to stain MCTC. Anti-COX-2 antibody was used to determine COX-2 expression. Myometrial tissue of control cases and leiomyoma sections were evaluated for the expressions of these molecular markers. Their median and range (min-max) values for each group were calculated (16) and then compared among the groups. Moreover, a possible correlation was investigated between COX-2 and MCs.

\section{Immunohistochemistry (IHC)}

The streptavidin-biotin-peroxidase method was performed for immunohistochemical staining. For each case, representative blocks were selected. Four micrometer-thick sections were cut, and deparaffinized with xylene and ethanol. For COX-2 and tryptase/chymase staining, to retrieve the antigen, the deparaffinized slides were first heated in a microwave oven for $20 \mathrm{~min}$ in $10 \mathrm{mM}$ citrate buffer ( $\mathrm{pH}$ 6.0) for all markers followed by cooling at room temperature for $20 \mathrm{~min}$. and washing twice with PBS. All sections were incubated with $30 \mathrm{~mL} / \mathrm{L}$ hydrogen peroxide for $10 \mathrm{~min}$. to inhibit endogenous peroxidase then washed twice with PBS. After incubation with ultra $\mathrm{V}$ Bloc, treatment with primary antibody at room temperature at a dilution of 1:100 for COX-2 and 1:2000 for tryptase/chymase was performed using the following antibodies: rabbit polyclonal antibody against COX-2 (Neomarkers, Thermoscientific, UK) and mouse monoclonal antibodies against tryptase/chymase (Neomarkers, Thermoscientific, UK) for 20 min. and 30 min., respectively.

Sections were then incubated with biotinylated goat anti-polyvalent and streptavidin peroxidase each for $15 \mathrm{~min}$. at room temperature. The color was developed with 3-amino-9- ethyl-carbazole (AEC) (Thermoscientific) for $15 \mathrm{~min}$ at room temperature and counterstained with Mayer hematoxylin for $30 \mathrm{sec}$.

\section{Assessment of COX-2 and Tryptase Staining}

Immunohistochemical staining for COX-2 (Fig. 1) and tryptase/ chymase (Fig. 2a, b) in the myometrium of control uterine sections and in leiomyoma were semi-quantitatively evaluated in a blind fashion. For COX-2, cytoplasmic staining was defined as positive in muscle cells. An estimate of the percentage of immunoreactive cells was determined using a score of 0-3 (0: $0-4 \%$ cells stained; 1 : $5-29 \%$ cells stained; 2 : $30-59 \%$ cells stained; and 3: 60$100 \%$ cells stained). The staining intensity was scored as $0-3(0$, negative; 1 , weak; 2 , moderate; 3 , strong). Values for the quantity and staining intensity scores were then multiplied, giving results that ranged from 0 to 9 . 
The expression levels of COX-2 were recorded according to the following scoring criteria: grade 1 (score 0); grade 2 (scores 1 to 3 ); grade 3 (scores 4 to 6); grade 4 (scores 7 to 9) $(17,18$ ). The median and range (min-max) values of the staining grades for COX-2 in both groups were compared with each other.

The mean number of tryptase/chymase-positive MCs (MCT/ MCTC) per 5 fields with the most abundant infiltration at a magnification of X400 (19) was counted in the control myometrium and the leiomyoma, and the mean numbers were noted in each group. The calculation was performed on the photograph of the fields on computer. MCT actually reflects the number of total MCs, so we used anti-tryptase antibody to assess total MC count, as well.

In order to make a correlation between mean values of $\mathrm{MCT}$ and COX-2 grades, the mean MCT number was graded according to

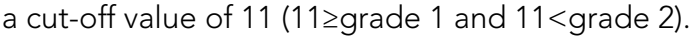

\section{Statistical Analysis}

Statistical analysis was performed by SPSS 11.0 for Windows software. The immunohistochemical data are reported as median and range (min-max) value. Comparison of the means between 2 groups were determined using the nonparametrical Mann-Whitney $\mathrm{U}$ test. Bivariate correlation between variables was estimated by Spearman correlation coefficients. A $p$ value $<0.05$ was considered significant.

\section{RESULTS}

\section{COX-2 Expression in control and leiomyoma}

Immunoreactivity was observed in the cytoplasm of muscle cells. Expression of COX-2 was also found in inflammatory cells such as plasma cells. In the control group, the median value of COX-2 staining grade was 3 (min:2-max:4). In leiomyoma, the median value of COX-2 staining grade was 2 (min:1-max:3), which was statistically lower than that of the control $(p=0,001)($ Table 1$)$. No correlation was seen between myometrial COX-2 expressions and tryptase/chymase expressions in both groups.

\section{Tryptase, Chymase Expressions in control and leiomyoma}

The median value of tryptase expression (MCT) was 12 (min:10max:16) in the control myometrium, slightly higher than that of the leiomyoma group with a median value of 10.5 (min:6-max:15).

The median value of chymase expression (MCTC) was 7 (min:4max:13) in the control myometrium, significantly higher ( $p=0.001)$ than that of the leiomyoma group with a median value of 5 (min:2-max:8). Thus, in the leiomyoma group, the MC including tryptase $\div \mathrm{MC}$ including chymase (MCT/MCTC) proportion was significantly higher than the control $(p=0.032)$..MC subtypes neither correlated with each other nor with COX-2 expression in the leiomyoma and control groups.

\section{DISCUSSION}

MCs are multifunctional cells and it has recently been shown that they can act as effector elements of the human immune system. In vitro and in vivo studies have also linked MC degranulation and activation with angiogenesis and neovascularization. Recently, MC tryptase was found to be a novel and potent angiogenic factor (20). Although some authors postulate MCs to be enhancers of tumor development, especially through their effects on angiogenesis, mounting evidence indicates that MCs could inhibit tumor growth (21).
MCs are known to be located at peritumoral and intratumoral sites, playing an active role physiologically or pathologically. $M C$ infiltration and activation in tumors are mainly mediated by tumor-derived stem cell factor and its receptor c-kit on MCs. Several types of tumor cells exhibit an increased production of stem cell factor, which stimulates MC migration, proliferation, and degranulation (22).

On the other hand, COX-2 is an immediate early response gene that can be induced by a variety of tumor promoters, cytokines, growth factors and hypoxia. Many epidemiological studies demonstrate that treatment with non-steroidal anti-inflammatory drugs (NSAIDs) reduce the incidence and mortality of certain malignancies, especially gastrointestinal cancer. The cyclooxygenase (COX) enzymes are well-known targets of NSAIDs. However, conventional NSAIDs non-selectively inhibit both the constitutive form COX1 , and the inducible form COX-2. Recent evidence indicates that COX-2 is an important molecular target for anticancer therapies. It is now well-established that COX-2 is chronically overexpressed in many premalignant, malignant, and metastastic cancers (23).

First of all, in our study we found that both mast cell subtypes MCT and MCTC were reduced in the leiomyoma compared to thecontrol group. Contrary to our result, Lü et al. (24) reported an increased MCD in leiomyoma. Another study found significantly higher $\mathrm{MC}$ numbers in cellular leiomyoma compared to endometrial stromal sarcoma (25). Nevertheless, MCs were found to be decreased significantly in some endometrial lesions such as atypical hyperplasia, endometrial sarcoma, and carcinoma $(26,27)$. Additionally, in our previous study we compared MCD between endometrial carcinoma (EC) and leiomyoma and found that, in $E C$, the MCD was $9.7 \pm 2.4$ (the mean number of tryptase-positive MCs (MCT) per 5 fields, with the most abundant infiltration at a magnification of $\mathrm{X} 400$ ) cell per in the myometrium, significantly lower than that of control $(p=0.01)$, but not much different from that of leiomyoma $(p=0.336)(28)$.

Another finding of our current study was a proportional change in mast cell subtypes. We found that the tryptase $\div$ chymase ratio was increased in the leiomyoma group, due to the significant reduction of MCTC vs. slight reduction of $\mathrm{MCT}$ in leiomyoma. Consistent with our study, a proportional change in $\mathrm{MC}$ subtypes was observed in some tumors, for example, lip carcinoma (29). In contrast, some studies revealed no proportional change such as in colorectal, pulmonary, and hepatocellular carcinoma (30).

In this context, MC mediators produce different functions and the coexistence of both $\mathrm{MC}$ subtypes contributes to tissue homeostasis. Since mediators have been shown to influence various aspects of tumor biology, the net effect of $M C$ in the tumor progression is difficult to evaluate. For instance, chymase was demonstrated to induce apoptosis in some targets; yet, tryptase is thought to be an angiogenic factor.

\begin{tabular}{|c|c|c|c|}
\hline Molecular markers & cox-2 & MCT & МСТС \\
\hline Control (Group 1) & $3(2-4)$ & $12(10-16)$ & $7(4-13)$ \\
\hline Leiomyoma Uteri (Group 2) & $2(1-3)$ & $10.5(6-15)$ & $5(2-8)$ \\
\hline
\end{tabular}


Availability of MCs in inflamed and ulcerated tissues also raises the question about MCs, whether they are really functioning as an active player or are just an innocent passerby. In fact, MCs might only be a reflection of a generalized inflammatory reaction of the immune system. Some researchers suggest that MCs may represent reactive cell types involved in the pathophysiology of the host reaction. Actually, in this cytokine storm, it is very reasonable to think that MCs may change its mediator content, and the observed increased tryptase $\div$ chymase ratio could be actually secondary to the environmental inflammatory changes in the tumor stroma. Our correspondences on the role of $\mathrm{MC}$ in tumor tissue are also well documented in the recent literature (31-33).

Furthermore, in our study we found that COX-2 expression was lower in leiomyoma than the control myometrium. Conversely, COX-2 expression in endometrial cancer and hyperplasia was found to be increased compared to normal endometria, and the increased COX-2 expression in hyperplasia was suggested to be an indication of an early step in carcinogenesis (34). Interestingly, in an animal model studying uterine leiomyoma in the context of pregnancy-associated changes in gene expression, leiomyoma cells were found to express many genes of the parturient myometrium, but were deficient in COX-2 expression (35).

On the other hand, increased COX-2 expression is one of the characteristics of some tumors, such as in endometrial cancer. Overexpression of COX-2 may induce the expression of VEGF, increase angiogenesis, and enhance tumor growth in endometrial carcinoma (36). Cyclooxygenase-2 (COX-2) overexpression is considered to be a significant predictor of actinic cheilitis malignisation, as well (37). Thus, the literature shows increasing evidence that overexpression of the COX-2 plays an important role in tumor growth and spread of tumors by interfering with different biological processes such as cell proliferation, cellular adhesion, immune surveillance, apoptosis, inflammation, and angiogenesis. COX-2 overexpression itself was also found to reduce peritumoral CD8+ $\mathrm{T}$ cell infiltration. Nevertheless, the tumorigenic mechanisms of COX-2 overexpression still remains poorly understood and may include mechanisms that may act at different stages of the disease. Also, contrary to these data; some studies could not demonstrate any association between COX2 overexpression and survival. Some researchers even showed better survival in tumors with COX-2 overexpression (38). Thus, COX-2 overexpression in tumors does not always mean poor prognosis and there appears to be many other factors mediating its expression other than tryptase. Nevertheless, we believe that our finding of the lower levels of COX-2 in leiomyoma may be a characteristic of benign lesions.

We also checked for a correlation between COX-2 and MCT and MCTC in leiomyoma and controls. We found no correlation between COX-2 and MC subtypes in leiomyoma or control myometrium. Actually, no statistically significant correlation was found, but all three markers were found to be reduced in leiomyoma compared to the control group Partially supporting our findings, COX-2 expressing cells and the number of mast cells were found to be decreased in hepatocellular carcinoma with progression of the disease (39). Conversely, COX-2 overexpression in actinic cheilitis was found to be associated with increased tryptase-positive MCs, suggesting tryptase as a contributory factor for COX-2 up-regulation (37).
In conclusion, this study has demonstrated that MC subtypes neither correlate with each other nor with COX-2 expression in the leiomyoma and control groups, and the proportion of MC subtypes is changed in the tumor microenvironment. Even though it is hard to explain the conflicting results in the literature, they may be due to wide variations in the timing of studies related to tumor type as well as methodologies which were used for demonstration of MC, its mediators, inflammatory cells and vessels. Because of the conflicting reports about this issue, further studies

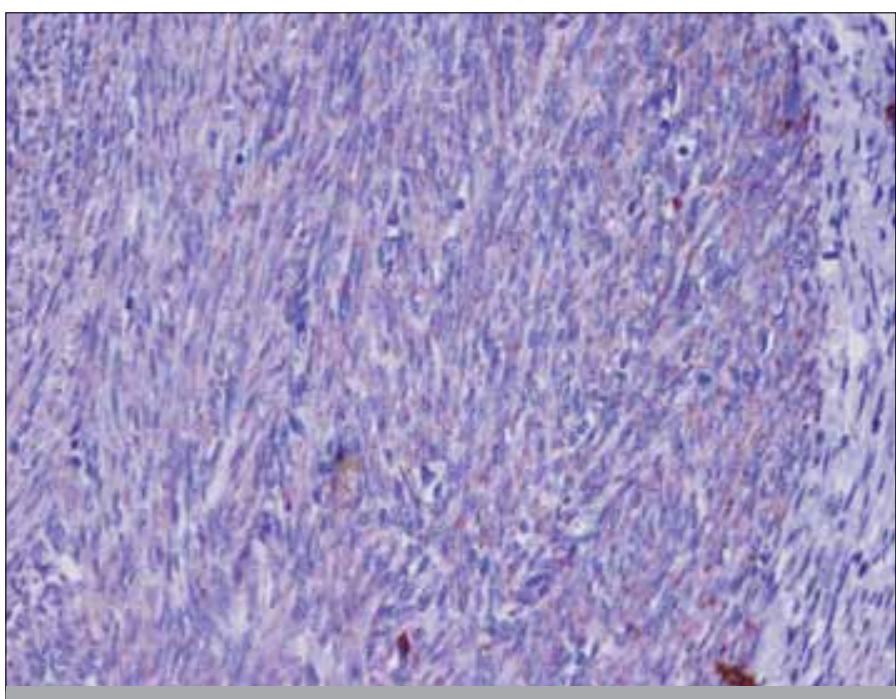

Figure 1. Moderate immunostaining with COX-2 (staining grade 3 ) in the myometrial cells of leiomyoma uteri (x200)
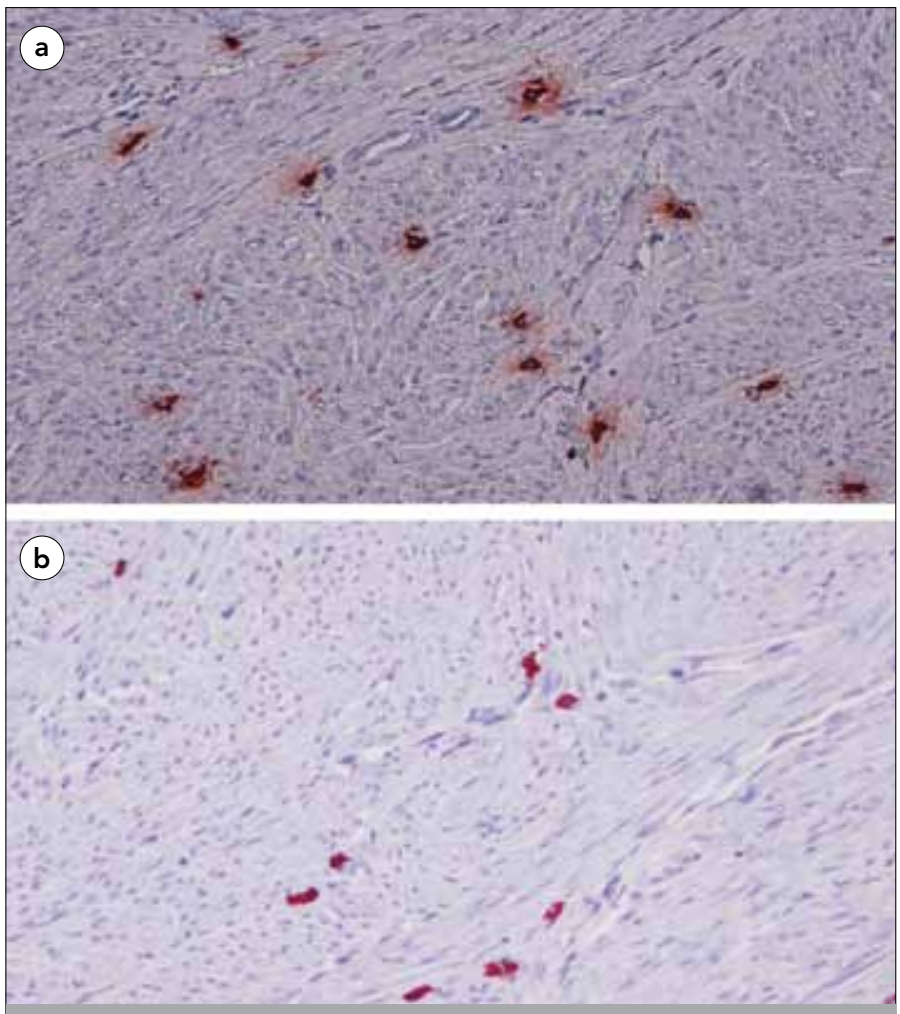

Figure 2. a. Immunostaining with tryptase (with a mean value of 6 cells per field in $\times 40$ objective) in the leiomyoma uteri $(x 200)$, b. Immunostaining with chymase (with a mean value of 5 cells per field in $\times 40$ objective) in the leiomyoma uteri $(x 200)$ 
are required. Understanding the mechanisms of the MC function via secretory molecules provides a basis for a rational approach to the development of antitumoral therapy in patients with leiomyoma and other tumors.

\section{Acknowledgements}

We obtained financial support for kits and consumables used for this research from the Afyonkocatepe University, Scientific Research Projects Foundation with project number 10.tip.10.

Conflict of interest: No conflict of interest was declared by the authors.

\section{REFERENCES}

1. Wallach EE, Vlahos NF. Uterine myomas: an overview of development, clinical features, and management. Obstet Gynecol 2004; 104 : 393-406. [CrossRef]

2. Vollenhoven BJ, Herington AC, Healy DL. Epidermal growth factor and transforming growth factor-beta in uterine fibroids and myometrium. Gynecol Obstet Invest 1995; 40: 120-4. [CrossRef]

3. Van der Ven LT, Roholl PJ, Gloudemans T, Van Buul-Offers SC, Welters MJ, Bladergroen BA, et al. Expression of insulin-like growth factors (IGFs), their receptors and IGF binding protein-3 in normal, benign and malignant smooth muscle tissues. Br J Cancer 1997; 75: 1631-40. [CrossRef]

4. Norrby K, Woolley DE. Role of mast cells in mitogenesis and angiogenesis in normal tissue and tumour tissue. In: Histamine in Normal and Cancer Cell Proliferation; Garcia-Caballero M, Brandes LJ, Hosoda $\mathrm{S}$, eds. Advances in the biosciences. Vol 89. Oxford: Pergamon Press, 1993: 71-116

5. Ribatti D, Vacca A, Marzullo A, Nico B, Ria R, Roncali L, et al. Angiogenesis and mast cell density with tryptase activity increase simultaneously with pathological progression in B-cell non-Hodgkin's lymphomas. Int J Cancer 2000; 85: 171-5. [CrossRef]

6. Irani AA, Schechter NM, Craig SS, DeBlois G, Schwartz LB. Two types of human mast cells that have distinct neutral protease compositions. Proc Natl Acad Sci U S A 1986; 83: 4464-8. [CrossRef]

7. Irani AM, Craig SS, DeBlois G, Elson CO, Schechter NM, Schwartz LB. Deficiency of the tryptase-positive, chymase-negative mast cell type in gastrointestinal mucosa of patients with defective $T$ lymphocyte function. J Immunol 1987; 138: 4381-6.

8. Bradding P, Okayama Y, Howarth PH, Church MK, Holgate ST. Heterogeneity of human mast cells based on cytokine content. J Immunol 1995; 155: 297-307.

9. Ozdemir $O$. The role of mast cell and mast cell subtypes $(\mathrm{MC}(\mathrm{T})$ and $\mathrm{MC}(C T))$ in tumor angiogenesis. Eur J Cardiothorac Surg 2006; 29: 638-9. [CrossRef]

10. Cao Y, Prescott SM. Many actions of cyclooxygenase-2 in cellular dynamics and in cancer. J Cell Physiol 2002; 190: 279-86. [CrossRef]

11. Tsujii M, Kawano S, Tsuji S, Sawaoka H, Hori M, DuBois RN. Cyclooxygenase regulates angiogenesis induced by colon cancer cells. Cell 1998; 93: 705-16. [CrossRef]

12. Ali-Fehmi R, Che M, Khalifeh I, Malone JM, Morris R, Lawrence WD et al. The effect of cyclooxygenase-2 expression on tumor vascularity in advanced stage ovarian serous carcinoma. Cancer 2003; 98: 1423-9. [CrossRef]

13. Naghshvar F, Torabizadeh Zh, Emadian O, Enami K, Ghahremani M. Correlation of cyclooxygenase 2 expression and inflammatory cells infiltration in colorectal cancer. Pak J Biol Sci 2009: 12: 98-100. [CrossRef]

14. Rahman MA, Dhar DK, Yamaguchi E, Maruyama S, Sato T, Hayashi H, et al. Coexpression of inducible nitric oxide synthase and COX-2 in hepatocellular carcinoma and surrounding liver: possible involvement of COX-2 in the angiogenesis of hepatitis $\mathrm{C}$ virus-positive cases. Clin Cancer Res 2001; 7: 1325-32.

15. Cheng AS, Chan HL, To KF, Leung WK, Chan KK, Liew CT, et al. Cyclooxygenase-2 pathway correlates with vascular endothelial growth factor expression and tumor angiogenesis in hepatitis $B$ virus-associated hepatocellular carcinoma. Int J Oncol 2004; 24: 853-60.

16. Cervello M, Foderàa D, Florena AM, Soresi M, Tripodo C, D'Alessandro $\mathrm{N}$, et al. Correlation between expression of cyclooxygenase-2 and the presence of inflammatory cells in human primary hepatocellular car- cinoma: possible role in tumor promotion and angiogenesis. World $J$ Gastroenterol 2005; 11: 4638-43.

17. Sun WH, Sun $Y L$, Fang RN, Shao $Y, X u H C$, Xue QP, et al. Expression of cyclooxygenase-2 and matrix metalloproteinase-9 in gastric carcinoma and its correlation with angiogenesis. Jpn J Clin Oncol 2005; 35: 707-13. [CrossRef]

18. Tokyol C, Aktepe F, Dilek FH, Sahin O, Arioz DT. Expression of cyclooxygenase-2 and matrix metalloproteinase-2 in adenomyosis and endometrial polyps and its correlation with angiogenesis. Int J Gynecol Pathol 2009; 28: 148-56. [CrossRef]

19. Tan SY, Fan Y, Luo HS, Shen ZX, Guo Y, Zhao LJ. Prognostic significance of cell infiltrations of immunosurveillance in colorectal cancer World J Gastroenterol 2005; 11: 1210-4.

20. Blair RJ, Meng H, Marchese MJ, Ren S, Schwartz LB, Tonnesen MG, et al. Human mast cells stimulate vascular tube formation. Tryptase is a novel, potent angiogenic factor. J Clin Invest 1997; 99: 2691-700. [CrossRef]

21. Della Rovere F, Granata A, Monaco M, Basile G. Phagocytosis of cancer cells by mast cells in breast cancer. Anticancer Res 2009; 29: 3157-61.

22. Turner AM, Zsebo KM, Martin F, Jacobsen FW, Bennett LG, Broudy VC. Nonhematopoietic tumor cell lines express stem cell factor and display c-kit receptors. Blood 1992; 80: 374-81.

23. Cervello M, Montalto G. Cyclooxygenases in hepatocellular carcinoma. World J Gastroenterol 2006; 12: 5113-21.

24. Lü JQ, Zhu XQ, Dong K, Xiang M, Lin Y, Hu Y. Study of the mechanism of mast cell increase in cellular leiomyoma of uterus. Zhonghua $\mathrm{Fu}$ Chan Ke Za Zhi 2007; 42: 390-3.

25. Zhu XQ, Shi YF, Zhou CY. Mast cells in cellular leiomyoma and endometrial stromal sarcoma of the uterus. Zhonghua Zhong Liu Za Zhi 2004; 26: 168-72.

26. Ribatti $D$, Finato N, Crivellato E, Marzullo A, Mangieri D, Nico B, et al. Neovascularization and mast cells with tryptase activity increase simultaneously with pathologic progression in human endometrial cancer. Am J Obstet Gynecol 2005; 193: 1961-5. [CrossRef]

27. D'Souza OA, Rameshkumar K, Nirmala V. Mast cells and macrophages in endometrial lesions. Indian J Pathol Microbiol 1994; 37: 367-73.

28. Goksu Erol AY, Tokyol C, Ozdemir O, Yilmazer M, Arioz TD, Aktepe F. The role of mast cells and angiogenesis in benign and malignant neoplasms of the uterus. Pathol Res Pract 2011; 207: 618-22. [CrossRef]

29. Rojas IG, Spencer ML, Martínez A, Maurelia MA, Rudolph MI. Characterization of mast cell subpopulations in lip cancer. J Oral Pathol Med 2005; 34: 268-73. [CrossRef]

30. Mauro LV, Bellido M, Morandi A, Bonadeo F, Vaccaro C, Quintana GO, et al. Association between mast cells of different phenotypes and angiogenesis in colorectal cancer. Mol Med Report 2008; 1: 895-902.

31. Erol AY, Ozdemir O. Do mast cell phenotypes play a role in concomitantly increased microvessel density and progression of non-small cell lung cancer? Hum Pathol 2011; 42: 1056-7. [CrossRef]

32. Erol YA, Ozdemir O. Mast cells: Are they really related to invasiveness of endometrial carcinoma? Pathol Res Pract 2010; 206: 426-7. [CrossRef]

33. Göksu Erol AY, Özdemir Ö. Newly Defined Roles of Mast Cells in Surgical Diseases and Surgical Tumors: Review. Turkiye Klinikleri J Med Sci 2011; 31: 969-75. [CrossRef]

34. Orejuela FJ, Ramondetta LM, Smith J, Brown J, Lemos LB, Li Y, et al. Estrogen and progesterone receptors and cyclooxygenase-2 expression in endometrial cancer, endometrial hyperplasia, and normal endometrium. Gynecol Oncol 2005; 97: 483-8. [CrossRef]

35. Cesen-Cummings K, Houston KD, Copland JA, Moorman VJ, Walker $\mathrm{CL}$, Davis BJ. Uterine leiomyomas express myometrial contractile-associated proteins involved in pregnancy-related hormone signaling. J Soc Gynecol Investig 2003; 10: 11-20. [CrossRef]

36. Li W, Xu RJ, Zhang HH, Jiang LH. Overexpression of cyclooxygenase-2 correlates with tumor angiogenesis in endometrial carcinoma. Int J Gynecol Cancer 2006; 16: 1673-8. [CrossRef]

37. Rojas IG, Martínez A, Brethauer U, Grez P, Yefi R, Luza S, et al. Actinic cheilitis: epithelial expression of COX-2 and its association with mast cell tryptase and PAR-2. Oral Oncol 2009; 45: 284-90. [CrossRef]

38. Zafirellis K, Agrogiannis G, Zachaki A. Prognostic value of COX-2 immunohistochemical expression evaluated by quantitative image analysis in colorectal cancer. APMIS 2008; 116: 912-22. [CrossRef]

39. Cervello M, Foderàa D, Florena AM, Soresi M, Tripodo C, D'Alessandro $\mathrm{N}$, et al. Correlation between expression of cyclooxygenase-2 and the presence of inflammatory cells in human primary hepatocellular carcinoma: possible role in tumor promotion and angiogenesis. World $\mathrm{J}$ Gastroenterol 2005; 11: 4638-43. 